\title{
THE TRANSFORMATION OF CHILDHOOD IN A MODERN SOCIETY AND ITS EDUCATIONAL CONTEXT
}

\author{
Tomasz Biernat \\ Nicolaus Copernicus University in Toruń, Poland
}

\begin{abstract}
The main aim of this article is to discuss two ways of perception of childhood in a modern society. The first way, which is preferred by essentialists, refers to the biological background of childhood and its traditional meanings. The second way of understanding childhood treats childhood as a kind of social construct. Both definitions bring up various consequences in the institutional education, raising children in families as well as in socialization of the young generation and sharing responsibility for education.
\end{abstract}

Keywords: childhood, definition of childhood, changes of childhood, social constructivism, education

\section{Introduction}

The transforming childhood in a modern society becomes a fact. The technological revolution, globalization, modern media has given the impulse to create new conditions for childhood development. These changes compel to answer a few basic questions: What is childhood? How is childhood perceived in a modern society? What social phenomena are linked to the process of constructing childhood? What are the educational consequences of this process? The answer to this questions is not as simple as we may think. On first sight we can say that childhood is a child's state of being or a time during which one is a child. Scientifically, we may define childhood in two ways. On the one hand we can define it as a biological fact, on the other hand, we can define it as a kind of social construct. These two theoretical approaches have the various educational results. The transforming childhood allows us to formulate interesting questions concerning responsibility of parents, teachers, educational institutions and governments for child's social and psychological development.

\section{Childhood as a biological fact and a social construct}

Let us look at the first meaning of childhood as a biological fact. Essentialists believe that childhood is inborn. This point of view holds true for every culture in the whole history. Thus, childhood constitutes an unchangeable "essence". This is a natural stage of people's development determined by genes. The essentialists' point of view is that childhood has its own specific, internal 
nature. According to scientists who represent this theoretical background (Z. Freud, J. Piaget, E. Erikson) childhood has always existed. It assumes that childhood may have different forms but its nature is always the same. Lloyd deMause claims that childhood has only been discovered by people in their history 9deMause, 1974).

The second point of view is as follows: childhood is a kind of social construct. The social constructionists believe that childhood is an element of the created social reality (Berger, Luckmann, 19830. Childhood is constructed by society in various acts of everyday life, in discovering what a social reality is, in creating meanings and negotiating meanings. People use common procedures that are involved in creating social reality: describing social world, interpreting social facts, getting a common wisdom, etc.

It is necessary to emphasize the meaning of social context; a time in history and the economic conditions which influence the process of constructing childhood. Defining childhood depends on who defines it and when and where childhood occurs.

The second way of understanding childhood suggests that it does not exist. It is not an internal characteristic of a human being. Childhood has appeared in people's history as an effect of social needs. It appeared in their consciousness as a cultural phenomenon. People began to create childhood because of their need of it. We can say that childhood was invented (Aries, 1995).

Neil Postman reckons that childhood, as a social construct, appeared in XVII century (Postman, 1999). Earlier, people's life span was constituted of two phases: infancy and adulthood. A child was treated as an adult person when it began to speak. The invention of print influenced the development of school education and learning which became obligatory. Being a member of adult society required new abilities: reading and writing. A new social category appeared in that time: the pupils. Young people had their own particular activity, a separate time for playing, learning etc. It is worthwhile saying that the first theories of childhood were created in the Enlightenment.

There are also many people who are somewhere in the middle and agree with certain aspects of both social constructionism and essentialism; they may believe that there's some biological influence on childhood but that cultural ideas also have an important impact.

\section{The constructing of childhood in a modern society}

In this part of my paper I would like to discuss the relationship between childhood and society. I will try to show the place of childhood in a contemporary culture (the post-modernity, the late modernity or flexible modernity). Nowadays, we can notice particular paradoxes linked to childhood. 
They come from anambiguous and contradictory relationship between society and childhood. On the one hand, we can observe a development of a specific pseudo-childhood culture which is produced for children by adults (e.g. special music, movies, fashion, entertainment for children, a fight for children rights, a great number of institutions and organizations helping and supporting children). On the other hand, we may see the disappearance of natural, authentic childhood culture. The children's culture created for children by adults is equipped with artifacts from adult's world. Some of the research indicates a disappearance of genuine children's culture and places where it may exist. Again, on the one hand, we notice a particular romantic overestimation of childhood. A change of child's position in the family: from "the king pair witch a child" to "the king child with parents". The child is not in the center of family. The position of a child becomes worse. The center of the family is occupied by parents because of their professional work, a desire for success and flourishing career. But, on the other hand we may assume that childhood is being degraded by many various mechanisms which have appeared in our time. This tendency is connected to depreciation of childhood in society (e.g. negative birth rate in many countries, co called DINKS marriages (an acronym that stands for Double Income, No Kids), single life style, abortion, contraception).

There is a great number of phenomena of harming childhood in our world. We may mention a few of them:

- childhood is threatened by various forms of neglect and child abuse, by homelessness (about 100.000.000 homeless children living in the streets around the world), by military conflicts (approximately 300.000 children are believed to be soldiers);

- children are constrained by drugs, alcohol, violence, poverty and pornography;

- $\quad$ children have become a kind of taboo; untouchable because of their sexuality, adults are afraid of them due to the risk of being accused of sexual abuse;

- children have become a kind of taboo because of their violence and aggression (e.g. dangerous children at schools, on the streets).

All we can see is that childhood is deformed in many ways nowadays. Ayn Rand claims that the deformation of childhood in the modern society is caused by progressive and permissive education too (Rand, 2003).

David Elkind, a sociologist, suggests an appearance of a new construct of childhood: a postmodern child. It comes along with a post-modern family (Elkind, 1992). He defines this family as a set of the feelings, values and perceptions which determine the relations between the family and a wider society. This post-modern family is also called "a permeable family". His conception differs from Talcott Parsons' model of a modern family ("a nuclear family"). The main difference concerns the family boundaries which determine 
contact with outside world. The boundaries in the nuclear family are bright and sharp. They separate family from the world. The family is a place of safety and rest for its members. The boundaries within the permeable family differ. They are more permeable and facilitate closer contact with the outside world. This is a result of media development and the information revolution. The family is influenced by various elements coming from the outside world. A change of relations with the outside world brings new values, norms and life styles to the family. Finally, it changes the internal relations within families; first of all the relations between the parents and their children. The family structure, the family rules and roles, the boundaries between family members transform too. David Elkind recognizes that the post-modern families include families of working parents, divorced families, one parent families, foster families, lesbian and gay families with adopted children. In these families children and adults have lost their defined place. This fact changes the character of childhood.

The scientists suggest that a few new phenomena are connected to the childhood in our times. In early 80 's Neil Postman suggested the disappearance of childhood. In his opinion, this phenomenon is caused by children's access to information. What introduces a child to the adult world is its ability to use media technologies (Postman, 1982). David Elkind describes a phenomenon of shrinking childhood. He emphasizes three dimensions of it: shrinking of time of being a child, shrinking of social spheres destined for children and shrinking of normality (children are threatened by abnormal aspects of the adults' world). As a result of this transformation, childhood is damaged what threatens child's development (Elkind, 1994). Technology which has a great impact on child growth and development creates a "digital child" (Elkind, 2007).

Another problem concerns a multi-institutional secondary socialization. In a contemporary world the process of education is divided into various educational institutions. Education in the families and in various institutions is different. There is no communication between the participants of this process. The specialists admit that some aspects of education are out of control. I would like to point out to the changing character of raising children. In modern family, a great role in upbringing was played by intuition, custom and common sense. The subject of upbringing was a whole person (personality). The parents were focused on children's needs. The situation is changing now. Parents pay more attention to the techniques of upbringing. They want to influence children's behavior by teaching particular dispositions and abilities (self-esteem, communication, life style).

The next problem has appeared with new sources of child's identity. In our times the identity is flexible and more defined by social context than traditional influences coming from parents, teachers, priests. Personal narrative and the personal judgment of values seem to be less important. Adolescence is more 
peaceful and the need of separation manifested by youth is lower than in the past.

Some of the specialists in the field of childhood point out to another important fact. Children become adults earlier because they are consumers. They become active participants of a free market and have their own economic value. This group of consumers is one of the marketing targets. Children spend a lot of money (parents' of course). Zygmunt Bauman noticed that childhood in a materialistic society becomes a consumed good like many others goods for consumption (Bauman, 2007).

\section{The educational consequences of transforming childhood}

This conclusion brings to the light a few educational consequences. Let us look at them:

1. Childhood is an artifact of adulthood; the product of the adults' world.

2. A child who takes the role of an adult earlier than expected changes the relation between a child and an adult. The boundaries between adultness and childhood become invisible.

3. This situation places greater demands on the children by adults. The young generation is not prepared for their high expectations.

4. The children are threatened by dangerous situations coming from adults.

Neil Postman suggests a necessity of rescuing childhood. He treats childhood as an important social value. He emphasizes the meaning of the family, school and state in saving childhood. He asks: "How to protect childhood as a social value?" Phil Scraton in his book „The Childhood in Crisis” proposed to create a special childhood policy (Scraton, 1997). Doug Fileds suggests that parents should avoid the "instant adulthood" and shows the need of protecting childhood (Fields, 1994). The way of social perception of childhood is connected to decreasing value of child (Biernat, 2007).

At the end of this article, I would like to come back to the definition of childhood. If we treat childhood as a social construct we often deny the genetic component. We have to remember that even pure social construct may contain the genetic element. Parents and teachers construct childhood too. We may see how they do it in many various ways in their educational practices. Various definitions of childhood raise a few meaningful questions: whose is the childhood? Ours or children's? Who is responsible for childhood? The children, parents, teachers, institutions, or politicians and governments? Who has the rights to shape it? The answer these questions is very important for the understanding of the contemporary educational processes.

These questions are linked to educational context. How to educate children? How to maintain valuable relations between children and adults. How 
to describe the educational goals? How to communicate between different educational and cultural institutions that participate in education? How to create a self-reflexive identity of young people which could reconcile the contradictory influences coming from society? Each of us is obliged to give answers to them because it is the matter of our future.

\section{References}

Aries, P. (1995). Historia dzieciństwa. Dziecko i rodzina $w$ dawnych czasach. Gdańsk: Wydawnictwo Marabut.

Bauman, Z. (2007). Plynne życie. Warszawa: Wydawnictwo Literackie.

Biernat, T. (2007). Dziecko upragnioną wartością. In: L. Dyczewski (Ed.), Matżeństwo i rodzina w nowoczesnym społeczeństwie. Lublin: Wydawnictwo KUL.

Berger, P.L., Luckmann, T. (1983). Społeczne tworzenie rzeczywistości. Warszawa: PIW.

deMause, L. (1974). The history of childhood. New York: Psychohistory Press.

Elkind, D. (2007). Technology's impact on child growth and development. Downloaded from: http://www.commongroundspeakerseries.org/images/speakers2007_08/Elkind.pdf.

Elkind, D. (1992). The post-modern family. A new imbalance. New York: Knopf.

Elkind, D. (1994). Ties that stress: the new family imbalance. Cambridge: Harvard University Press.

Fields, D. (1994). Dorośli zbyt wcześnie. Warszawa: Oficyna Wydawnicza Vocatio.

Postman, N. (1982). Disapearance of childhood. London: Comet.

Postman, N. (1999).W stronę XVIII stulecia. Jak przeszłość może doskonalić nasza przyszłość. Warszawa: PIW.

Rand, A. (2003). Powrót człowieka pierwotnego. Rewolucja antyprzemysłowa. Poznań: Wydawnictwo Zysk i S-ka.

Scraton, P. (1997). Childhood in crisis? London: The University College London Press. 